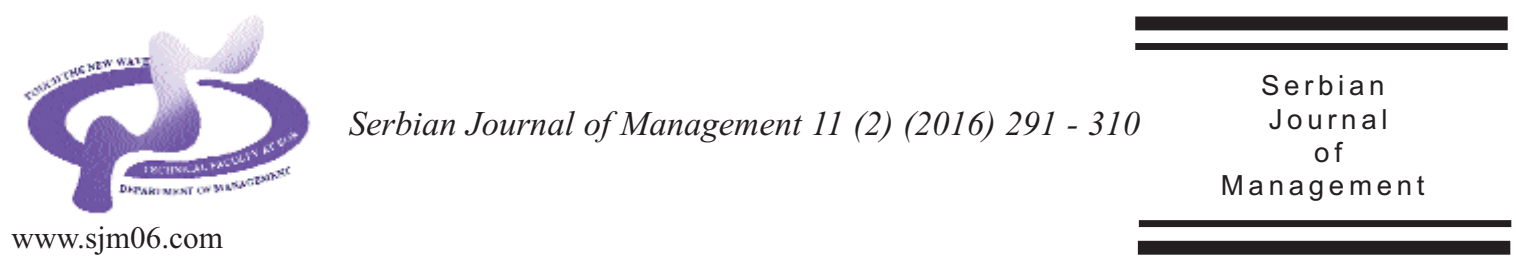

\title{
MARKET ENTRY STRATEGIES TO EMERGING MARKETS: A CONCEPTUAL MODEL OF TURNKEY PROJECT DEVELOPMENT
}

\author{
Bistra Vassileva* and Miroslav Nikolov \\ Centre Innovation and Development (CID) at the University of Economics-Varna \\ 77 Knjaz Boris I Boul., Varna, Bulgaria
}

(Received 2 May 2016; accepted 4 July 2016)

\begin{abstract}
The main purpose of the paper is to analyse the international market entry strategies in the light of globalisation processes and to propose a conceptual model of turnkey projects as market entry mode. The specific research objectives are as follows: 1. to develop an integrated framework of the turnkey marketing process as a conceptual model; 2. to analyse BRICS countries as potential host countries for turnkey projects implementation; 3. to assess potential implications of proposed conceptual model for global market entry decisions.
\end{abstract}

Keywords: international market entry strategies, turnkey projects, BRICS

\section{INTRODUCTION}

The world is changing with a speed which has never been seen before. The business environment nowadays is characterised by increasing complexity, uncertainty and discontinuity. Changing market conditions, intensifed global competition and increasingly shorter product life cycles mean that companies are having to re-examine the traditional methods and strategies for doing business (Bartlett \& Ghoshal, 1987; Ohmae, 1989). Global competition is growing and will continue to increase. According to the competitiveness roadmap 2007-2050 (Garelli, 2007) ${ }^{1}$ among the main issues with a high impact on world competitiveness environment during the next three decades are the following ones:

- Protectionism on the rise;

- Service and integration are key competitiveness factors;

\footnotetext{
* Corresponding author: bistravas@ue-varna.bg

DOI:10.5937/sjm11-10177
} 
- $\quad$ Labour cost differences shrink;

- The technological divide disappears;

- China, India and Russia as technological powers;

- Climate change affects economic resources.

It is argued that protectionist reprisal will increasingly confront acquisitions pursued by some of emerging economies due to perceptions of a potential loss of economic power and national image. Protectionist measures will include environmental protection, corporate governance, social protection or intellectual property. Emerging economies, as an opposite reaction, will significantly increase pressure to gain access to decision-making in international institutions by emphasising their predominant economic weight and their financial capabilities to fund such institutions (Garelli, 2007).

The importance of market entry strategies in internationalisation is widely recognised in the international marketing literature (Davidson, 1982; Ekeledo \& Sivakumar, 2004; Gatignon \& Anderson, 1988; Root, 1994; Terpstra \& Sarathy, 1994). To facilitate the adoption of an appropriate entry mode it is necessary to have conceptual models that are rooted in sound theories (Anderson \& Gatignon, 1986; Dunning, 1977). This paper further investigates the pros and cons of market entry modes in different categories of country-markets. It discusses the project marketing issues and especially turnkey projects as market entry mode in emerging markets (BRICS).

Following a synthesis of the international marketing strategies literature and the resource-based view toward international market entry mode strategies, we describe the research approach adopted in present paper. Afterward, we provide the findings of the research and develop a conceptual model of turnkey projects as a market entry mode. Finally, we discuss the implications of turnkey projects as a market entry strategy to emerging markets (BRICS).

In contributing to the literature at the international market entry strategies, two issues are investigated in the course of this study: first, turnkey projects as market entry strategy in emerging markets; and, second, turnkey project marketing process.

\section{GLOBALISATION AND MARKET ENTRY STRATEGIES}

\subsection{Globalisation and global business trends}

Globalisation is a complex process that has been at work, in various ways, and to different degrees (Clark et al., 2009). It is agreed that the debate around a consistent definition for globalisation has emerged from the field of international business. The definitional void stems from the fact that the word 'global' has been used in a variety of often contradictory ways (Clark \& Knowles, 2003). Scholars from different scientific fields focus on different aspects of globalisation that are relevant to their own disciplinary interests which neglects the fact that globalisation is a complex phenomena. Three common factors are identified by Clark and Knowles (2003) in most conceptualisations of globalisation: (1) integration of national/ regional phenomena into world sub-systems; (2) the process(es) by which this integration occurs; and (3) mechanisms that facilitate integration, by transmitting influence from one location to another. Inter-connectedness and interdependence comprise the very core of

\footnotetext{
${ }^{1}$ The „Competitiveness Roadmap” is an attempt to describe and assess the main issues that will affect the world competitiveness landscape. Issues are shown along two axes, degree of impact and time-scale. It is a subjective assessment which aims to bring some coherence to the multitude of issues that are said to be having an impact on the competitiveness landscape. The issues which are described are 45 with different levels of impact.
} 
these factors thus revealing the complex nature of globalisation.

There is no doubt that globalisation is a fact and that it will continue to affect companies and their marketing activities providing global market opportunities and/or raising global competitive threats. Combined with global market uncertainty, globalisation can be considered to be a global business driver (Table 1).

With the trend towards more interdependence among nations, several changes in the business environment have emerged: converging consumer demand, increasing trade and investment liberalisation, emergence of global markets for goods, services, labor and financial capital (Thoumrungroje, 2004). Hence, global markets became both a fundamental research topic and hot business issue.

Global business changes impose a certain level of transformation of both business models and market dimensions (Figure 1).

The transfer process from one dimension

Table 1. Global business drivers

\begin{tabular}{|c|c|c|}
\hline Driver & Description & \\
\hline Globalisation & $\begin{array}{l}\text { - } \begin{array}{l}\text { Realignment of global supply } \\
\text { chain }\end{array} \\
\text { - Economic shift from global } \\
\text { North to South }\end{array}$ & $\begin{array}{l}\text { - } \quad \text { Changing global governance } \\
\text { - } \quad \text { Elevated financial volatility } \\
\text { and risk } \\
\text { - } \quad \text { More inclusive globalisation }\end{array}$ \\
\hline Consumer behaviour & $\begin{array}{l}\text { - New models of consumer } \\
\text { engagement } \\
\text { - The insatiable consumer }\end{array}$ & $\begin{array}{l}\text { - New era of squeezed } \\
\text { profitability }\end{array}$ \\
\hline Demographics & - War for talent & - $\quad$ Growing infrastructure needs \\
\hline $\begin{array}{l}\text { Regulation and } \\
\text { activism }\end{array}$ & - Changing role of government & - Rising geopolitical instability \\
\hline $\begin{array}{l}\text { Environment and } \\
\text { natural resources }\end{array}$ & - Depleting natural resources & $\begin{array}{l}\text { - Responding to sustainability } \\
\text { challenge }\end{array}$ \\
\hline Technology & $\begin{array}{l}\text { - New paradigms in product } \\
\text { design and manufacturing }\end{array}$ & $\begin{array}{l}\text { - New and innovative R\&D } \\
\text { models }\end{array}$ \\
\hline
\end{tabular}

Source: Adapted by: Report of the Global Business Policy Council at A.T. Kearney

[available at: http://www.atkearney.com/gbpc/global-business-drivers]

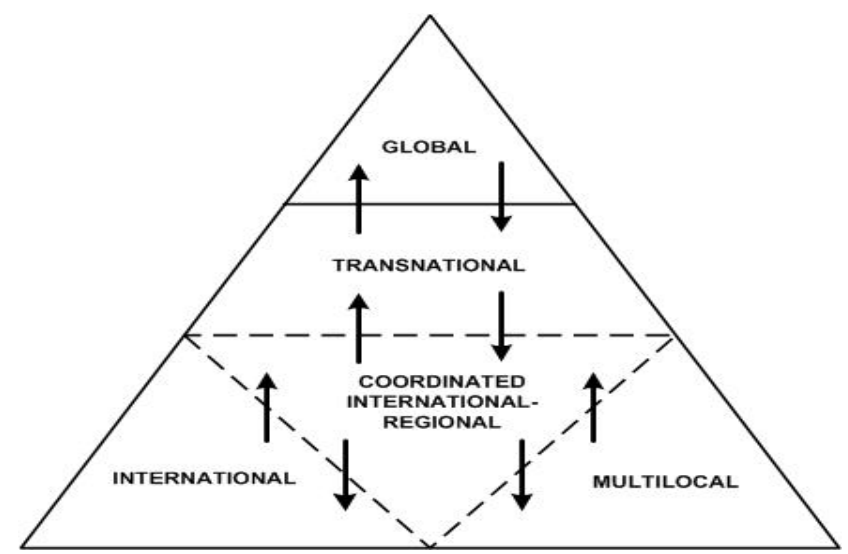

Source: Adapted by Ellis, J. and Williams, D. International Business Strategy, Pitman Publishing, 1995, p. 339.

Figure 1. Relationships "international-transnational-global" dimension 


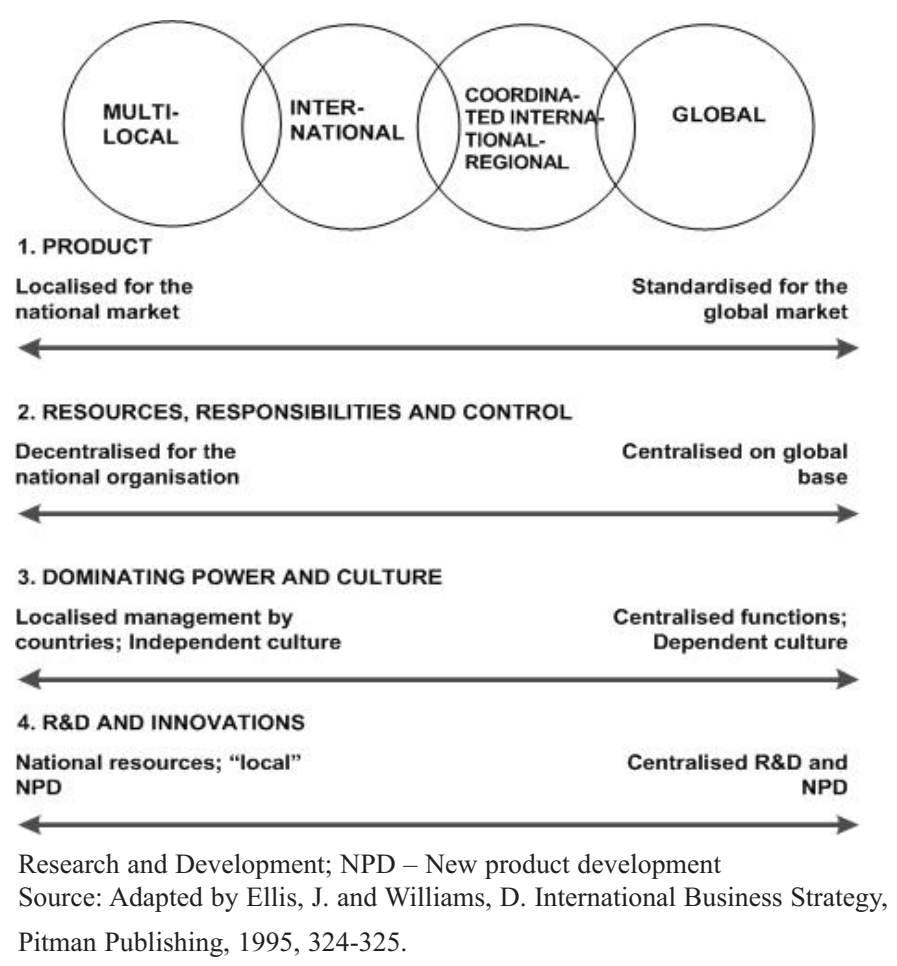

Figure 2. Basic forms of international business: differences by key characteristics

to another or from one business model to another depends on various internal and external factors. In reality quite frequently we can observe transition states with overlapping business models (Figure 2).

Years of research done by the McKinsey Global Institute (MGI) and McKinsey's Strategy Practice reveal three major economic forces the global economy has ever seen: the collision of technological disruption, rapid emerging-markets growth, and widespread aging. Much bigger shifts in each of these areas are expected which will tremendously affect economy, social life and personal behaviour worldwide.

First, technology and connectivity have disrupted industries and transformed the lives of billions of people in their different roles as workers, consumers and citizens. The KPMG report on complexity (2011) shows that technology is changing business models, improving processes, and opening new markets, but also creating volumes of new data that must be managed, supported, and secured. More transactions are taking place across more borders. Changing global regulatory environment is forcing businesses to react to ensure compliance while managing new risks. We are witnessing an extraordinary growth in computing capacity, power, and speed of ITC penetration ${ }^{2}$. This acceleration in the scope, scale, and economic impact of technology will be supplemented with a new age of artificial intelligence, consumer products and services, instant communication, and unlimited information which in turn will distress the business in unthinkable way. With instant information and communication, virtually everything is available to anyone, anywhere. Markets are now global and many corporations are often richer and more powerful than many countries.

\footnotetext{
${ }^{2}$ According to the Moore's Law, the overall processing power for computers doubles every two years.
} 
Second, the world's economic center of gravity has continued shifting from West to East, with China being at the centre of the trend. This shifting locus of economic activity and dynamism to emerging markets and to cities within those markets, will give rise to a new class of global competitors both companies and brands. The global urban population is growing by 65 million a year, and nearly half of global GDP growth between 2010 and 2025 will come from 440 cities in emerging markets, $95 \%$ of them being almost unknown small and mediumsized cities in emerging markets. According to the data provided by the Global Cities Index and Emerging Cities Outlook ${ }^{3}$ (Kearney, 2014) there are six cities from Asia in top 20 global cities and nine in top 20 emerging cities in 2014. Beijing is ranked in top 20 by both indices. This shifting balance of power has been indicated as a transition from Globalisation 2.0 (Western-dominated) to Globalisation 3.0 (China-dominated) (Walker, 2007) ${ }^{4}$. Globalisation 3.0 is characterised by the fact that the West no longer dominates the world's savings, and as a result no longer dominates global investment and finance. The erosion of Western power is accompanied by the erosion of the authority of the grand institutions of Globalisation 2.0, which sustained power by enforcing the implicit rules of Western economic orthodoxy. This situation is confirmed by the 2014 FDI Confidence Index ranking and scores 5 . The first and second place are occupied by United States and China with maintained ranking from 2013 (respectively 2.16 and 1.95 out of maximum 3.0$)^{6}$.
Third, the rapid aging of the world's population will create a massive set of economic pressure. Thebaby boomers have begun retiring. Aging has been evident in developed economies for few years, with Japan and Russia seeing their populations decline and the trend is spreading slowly to China. It is expected that during the next few years it will "reach" Latin America.

The researchers suggest that during the collision of these three forces, the resulting change will be so significant that much of the management and marketing expertise, knowhow and intuition that have served in the past will become irrelevant. Companies will face with more discontinuity and volatility, with long-term charts no longer looking like smooth upward curves, with outdated longheld assumptions, and useless formerly powerful business models (Dobbs et al., 2014).

\subsection{Country classification systems}

Over the years, researchers and practitioners have debated country classification issues (Nielsen, 2011). Several classification systems have been developed by international organisations and have been widely recognised. The UNDP's country classification system is built around the Human Development Index (HDI) launched together with the Human Development Report (HDR) in 1990. The classification systems in the World Bank are developed both for operational and analytical purposes. The operational classification satisfies the needs of the World Bank's International Bank for Reconstruction and Development

\footnotetext{
${ }^{3}$ A.T. Kearney‘s Global Cities Index (GCI) examines a comprehensive list of 84 cities, measuring how globally engaged they are across 26 metrics in five dimensions: business activity, human capital, information exchange, cultural experience, and political engagement since 2008. Emerging Cities Outlook (ECO) complements the GCI.

${ }^{4}$ The exact moment of the shift is considered to be the accession to WTO membership of China on December 11, 2001.

${ }^{5}$ The Foreign Direct Investment Confidence Index®, established in 1998 by A.T. Kearney, ranks countries based on how changes in their political, economic, and regulatory systems are likely to affect foreign direct investment inflows in the coming years.

${ }^{6}$ There are scholars (Dreher, 2006) who question the statistical significance of FDI Confidence Index since it covers only 67 countries, there is no clear explanation about the weights and cultural factors are excluded. They propose KOF Index of Globalisation which measures the three main dimensions of globalisation: economic, social and political, and includes sub-indices referring to: actual economic flows, economic restrictions, data on information flows, data on personal contact and data on cultural proximity. An alternative perspective to measuring globalisation from the perspective of nation-states can be found in UNCTAD's "Transnationality Index" (TNI). Although ostensibly a measure of how internationalised MNCs are, the TNI can also be construed as reflecting organisational responses to globalisation.
} 
Table 2. The World Bank's classification of countries

\begin{tabular}{lrrrr}
\hline Type of countries & Number & GDP, USD & $\begin{array}{r}\text { Population, } \\
\text { million people }\end{array}$ & $\begin{array}{r}\text { GDP per } \\
\text { person, USD }\end{array}$ \\
\hline Low income countries & 59 & 1165000 & 3094 & 380 \\
Lower middle income countries & 69 & 1635000 & 1099 & 1490 \\
Upper middle income countries & 42 & 2135000 & 498 & 4320 \\
High-income countries & 39 & 19304000 & 834 & 23150 \\
\hline
\end{tabular}

Source: TheWorldBank, EconomicReview, Vol. 11, 2000.

(IBRD) which has a statutory obligation to lend only to credit-worthy member countries. That is why an objective criteria are needed to assess the countries which need a credit. Under this system, countries that borrow from the IBRD and exceed a certain income threshold engage in a process that moves the country to non-borrowing status. The analytical country classification was constructed by the World Bank in 1978 . It has been modified in 1989 when the countries were divided into categories based on the income level.

Similar to the World Bank, the classification systems in the International Monetary Fund (IMF) are used for both operational and analytical purposes. Several analytical classifications have been developed during the years starting from 1948. According to IMF (Abiad et al., 2012) emerging market economies (EMs) and lowincome countries form a single category which is named Emerging Market and Developing Economies (EMDEs). According to the criteria established by the International Monetary Fund (IMF) an emerging market is defined by a GDP-percapita ratio that ranges between 2000 USD and 12000 USD.

\subsection{Theoretical background international market entry strategies}

A growing body of research in the area of "firms' behaviour on international markets" emphasises on the process of internationalisation of the business and its determinants. Numerous scholars tried to integrate the vast amount of research in this field into coherent topics (Aaby \& Slater, 1989; Andersen, 1993; Johanson \& Vahlne, 1992). However, there is no agreement on a common definition of the process of internationalisation in previous literature despite the scope of theoretical and empirical work which has been done during the years. Williamson (1975) and Dunning (1988) consider internationalisation as a form of investment on international markets. Johanson and Vahlne (1977) suggested that internationalisation should be observed as an evolutionary process where firm activities on international markets evolve in parallel with the following two factors: stage of management/firm involvement and market knowledge level. Such a process is not always smooth and sequential. Usually it integrates both internal and external forms of activities (Welch \& Luostarinen, 1993). According to Coviello and Mcauley (1999) the most comprehensive and holistic definition on the process of internationalisation is provided by Beamish (1990) who describes it as "...the process by which firms both increase their awareness of the direct and indirect influence of of international transactions on their future, and establish and conduct transactions with other countries". This definition presents a proper context to synthesise the diverse theoretical approaches toward internationalisation. 
Table 3. Theories of internationalisation

\begin{tabular}{|c|c|c|}
\hline $\begin{array}{l}\text { Theory of } \\
\text { international } \\
\text { market entry }\end{array}$ & Key authors & Short description \\
\hline $\begin{array}{l}\text { The Uppsala } \\
\text { internationalisa- } \\
\text { tion model }\end{array}$ & $\begin{array}{l}\text { Johanson \& } \\
\text { Vahlne, 1977; } 1992\end{array}$ & $\begin{array}{l}\text { Also known as a stage model because the } \\
\text { internationalisation is viewed as a consequent development } \\
\text { starting from geographically or culturally close markets and } \\
\text { expanding further. Another version of the model suggests } \\
\text { that firms should start with entry modes which require less } \\
\text { commitment and resources thus lower level of risk. }\end{array}$ \\
\hline $\begin{array}{l}\text { Transaction cost } \\
\text { theory }\end{array}$ & Williamson, 1981 & $\begin{array}{l}\text { The choice between full and particular internationalisation } \\
\text { depends upon the costs and the benefits of sharing the } \\
\text { resources relative to those of a wholly owned subsidiary. }\end{array}$ \\
\hline Eclectic Theory & $\begin{array}{l}\text { Dunning, 1995; } \\
2001\end{array}$ & $\begin{array}{l}\text { Internationalisation is considered to be a pattern of } \\
\text { investment in foreign markets explained by rational } \\
\text { economic analyses of ownership, location, and } \\
\text { internalisation, so called OLI advantages. }\end{array}$ \\
\hline $\begin{array}{l}\text { The network } \\
\text { approach }\end{array}$ & $\begin{array}{l}\text { Johanson \& } \\
\text { Mattsson, 1995; } \\
\text { Blankenburg, 1995; } \\
\text { Håkansson \& } \\
\text { Snehota, } 1995\end{array}$ & $\begin{array}{l}\text { The approach generally suggests that firms establish } \\
\text { relationships and enter networks in order to access } \\
\text { resources. The analysis is focused on networks of } \\
\text { relationships between firms in the global market. }\end{array}$ \\
\hline $\begin{array}{l}\text { The resource- } \\
\text { based theory }\end{array}$ & $\begin{array}{l}\text { Aaker, 1989; Amit } \\
\text { \& Schoemaker, } \\
\text { 1993; Barney, } \\
\text { 1991; Bharadwaj et } \\
\text { al., 1993; Conner, } \\
\text { 1991; Grant, 1991 }\end{array}$ & $\begin{array}{l}\text { The firm-specific resources (assets and capabilities) are } \\
\text { viewed as the drivers of a firm's business strategy. It } \\
\text { assumes sole ownership to be the default entry mode. } \\
\text { This fundamental assumption of the resource-based } \\
\text { approach is in sharp contrast with that of the transaction } \\
\text { cost approach. }\end{array}$ \\
\hline
\end{tabular}

These approaches are summarised by Johanson and Vahlne (1990) as follows: 1/ the FDI theory of internationalisation, 2/ the stage model of internationalisation, and 3/ the network approach to internationalisation. Table 3 provides a brief description of predominant theories of internationalisation process.

It has been suggested that organisational capabilities provide the richest explanation and prediction of entry mode choice in foreign markets (Madhok,1997). However, the application of the resource-based view to international market entry mode strategies has been primarily conceptual and descriptive. Systematic empirical research on entry mode choice, using the resourcebased perspective, is lacking despite the recognition that firm-specific resources drive successful business strategy (Ekeledo \& Sivakumar, 2004). Internalisation theory and the transaction cost theory are viewed as the same theory (Madhok, 1997; Rugman, 1980). Transaction cost theory strengthens the theoretical bases of market entry modes like sub-contracting, contract manufacturing, franchising and licensing.

Abovementioned theories of internationalisation (Table 3) sometimes are indicated as paradigms. The Uppsala internationalisation model forms the core of the geobusiness paradigm since it comprises three groups of variables (environmental, motivational and country-market variables). The relational paradigm has been developed by IMP Group 7 based on the background of the inter-

\footnotetext{
${ }^{7}$ International Marketing and Purchasing Group, http://www.impgroup.com/en/home/default.aspx
} 
organisational theory (Reve \& Stern, 1979; Sweeney, 1972; Van de Ven et al., 1974) and the theory of markets as hierarchies (Teece, 1983; Williamson, 1975). The paradigm "markets-networks" also focuses on relationships but within the boundaries of marketing system and networks of relations ${ }^{8}$. Within the framework of marketing system ${ }^{9}$ firms are observed as interdependent entities and their activities being coordinated through inter-relationships between the firms of the network. The paradigm "systemsexchanges" (Figure 3) includes part of the elements of previously presented paradigms.

The emphasis is placed on intrarelationships between institutions within the system which is explained as a set of regularly interacting groups which are coordinated to allow a formation of united whole and are organised to be able to fulfill previously defined goals (Carman, 1980). To overcome the challenges and to exploit the opportunities of global markets companies typically adopt one of the strategies presented in Table 4.

These strategies require adoption of different market entry modes. The impact of a firm's home country or host country on choice of entry mode is extensively covered in international business texts (such as Root, 1994; Terpstra \& Sarathy, 1994; Douglas \& Craig, 1995). Entry mode literature focuses on control because it is the most important determinant of risk and return (Anderson \& Gatignon, 1986). Control refers to the level of authority a firm may exercise over systems, methods, and decisions of the foreign affiliate (Ekeledo \& Sivakumar, 2004). The specific choice depends on the firm's resources, the market experience of the firm on the market, and the potential size of the market. Scholars (Bradley, 2005; Root, 1994) have proposed three broad categories of global market entry strategies which include:

- Export, import, and countertrade being the lowest level of entry (lowest level of management involvement) with limited control;

- Contractual entry strategies (franchising, licensing, management contracts and turnkey projects);

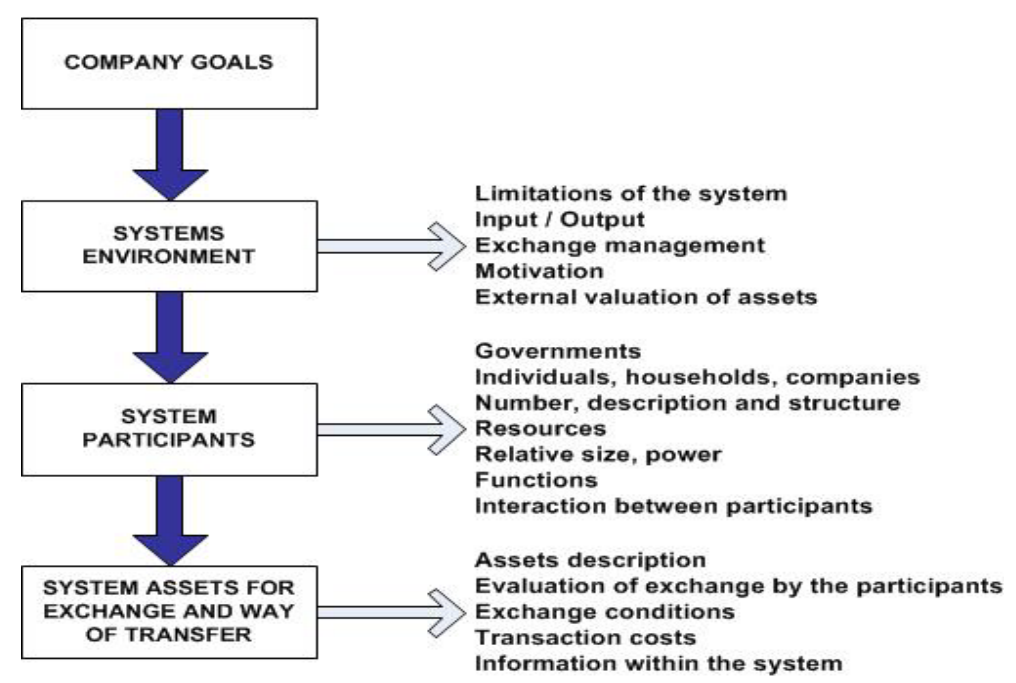

Source: Adapted by Carman, J.M. (1980), "Paradigms for Marketing Theory", Review in Marketing, No. 3, p. 4.

Figure 3. Paradigm ,systems-exchanges"

\footnotetext{
${ }^{8}$ This paradigm is presented in details for the first time from Johanson, J. and Mattsson, L.G. (1986). International marketing and internationalization process - a network approach, in Peter Turnbull and Stanley Paliwoda (eds.) Research in International Marketing, Croom Helm, London, pp. 242-243.

${ }^{9}$ More details about theoretical school of marketing systems could be found in: Alderson, W. (1965).Dynamic Marketing Behavior: A Functionalist Theory of Marketing, Homewood, Illinois, Richard D. Irwin.
} 
Table 4. Generic strategies to global markets

\begin{tabular}{|c|c|c|c|c|}
\hline \multirow{2}{*}{$\begin{array}{l}\text { Type of } \\
\text { strategy }\end{array}$} & \multirow[b]{2}{*}{ Description } & \multirow[b]{2}{*}{ Examples } & \multicolumn{2}{|c|}{ Suitable when level of } \\
\hline & & & flexibility & $\begin{array}{l}\text { global } \\
\text { efficiency }\end{array}$ \\
\hline $\begin{array}{l}\text { Home } \\
\text { replication } \\
\text { strategy }\end{array}$ & $\begin{array}{l}\text { Direct transfer of company's } \\
\text { competitive advantage from the } \\
\text { home market to the foreign market }\end{array}$ & $\begin{array}{l}\text { BMW, Audi, } \\
\text { Mercedes Benz, } \\
\text { Toy’s R Us }\end{array}$ & Low & Low \\
\hline $\begin{array}{l}\text { Multidomestic } \\
\text { strategy }\end{array}$ & $\begin{array}{l}\text { A company that operates with } \\
\text { relatively free subsidiaries in each } \\
\text { host market or customises its } \\
\text { marketing campaigns, products } \\
\text { and other operational techniques } \\
\text { in a situation of high cultural } \\
\text { differences. }\end{array}$ & Unilever, Kraft & High & Low \\
\hline $\begin{array}{l}\text { Global } \\
\text { Strategy }\end{array}$ & $\begin{array}{l}\text { Production of standardised } \\
\text { products and services to achieve a } \\
\text { very high level of economies of } \\
\text { scale, standardised marketing } \\
\text { campaigns and standardised } \\
\text { distribution system. }\end{array}$ & Sony, Coca-cola & Low & High \\
\hline $\begin{array}{l}\text { Transnational } \\
\text { Strategy }\end{array}$ & $\begin{array}{l}\text { A balanced decentralised } \\
\text { approach trying to combine the } \\
\text { advantages of global strategy } \\
\text { (economies of scale) and } \\
\text { multidomestic } \\
\begin{array}{l}\text { (decentralised decision making } \\
\text { process). }\end{array}\end{array}$ & IKEA & High & High \\
\hline
\end{tabular}

Source: Adapted by Lymbersky, C. (2008). Market Entry Strategies: Text, Cases and Readings in Market Entry Management, 1st edition, Management Laboratory Press, p. 29

- Investment entry strategies (wholly owned subsidiaries, joined ventures, M\&A, strategic alliances).

Turnkey projects are a type of collaborative arrangement in which a firm handles all operations and details for the host country client, mainly by building complete, ready-to-operate facilities. Turnkey operations as a market entry mode are suitable where the know-how is required to assemble and run a technologically complex process and/or when there are regulations preventing FDI. They are less risky than investment strategies which is a typical feature for all contractual market entry modes. Turnkey projects could be considered as a specific type of project marketing as well. From a marketing perspective project "is a complex transaction concerning a package of products, services and works, designed specially to realise in a certain period of time a specific asset for a client" (Cova \& Holstius, 1993). Thus turnkey projects could be characterised through the D-U-C model (Mandják \& Veres, 1998) which positioned the discontinuity, the uniqueness and the complexity of each project as specific dimensions of project activities. Economic discontinuity of project business places the supplier in a fragile and even risky position because of the higher bargaining power of customers. In order to overcome this shortcoming it is advisable to find possibilities to recreate continuity especially with significant customers and actors through the network of relations (Cova \& Salle, 2007). 


\section{METHODOLOGY AND FINDINGS}

\subsection{Methodology}

\subsubsection{Research purpose and objectives}

The main purpose of the paper is to analyse the international market entry strategies in the light of globalisation processes and to propose a conceptual model of turnkey projects as market entry mode. The specific research objectives are as follows: 1/ to develop an integrated framework of the turnkey marketing process as a conceptual model; 2/ to analyse BRICS countries as potential host countries for turnkey projects implementation; 3 / to assess potential implications of proposed conceptual model for global market entry decisions.

\subsubsection{Research methods and techniques}

The paper is conceptual by its nature. Detailed literature review on the key topics of globalisation and internationalisation has been performed. A special attention was given to global market entry strategies. Additionally, several in-depth interviews with experts in international project business and international complex projects implementation have been conducted. The interviews were audiotaped and trascripted afterwards. Based on achieved results a conceptual model was developed. An analysis of secondary data (as a part of feasibility analysis) for BRICS countries was done as well.

\subsubsection{Conceptual model}

According to the last developments of the definition of project activities presented by researchers in the field of project business it is the firm and not the project which is the unit of pertinent analysis (Artto \& Wikstrom, 2005). That is why, the investor is the focal element in our conceptual model (Figure 4).

Project markets are characterised by the intervention of numerous business and nonbusiness actors (Hadjikhani \& Thilenius, 2005) throughout the whole project cycle. For example, starting from the very beginning of the turnkey project development the investor could be a government or an international organisation/institution (both non-business actors). Following the project cycle, financing is one of the most critical elements for turnkey project success. International money lenders are non-business actors as well (Welch, 2005). When different actors from different countries (and international organisations as well) are involved it is vital to identify and analyse these actors, their roles and inter-relations, and their influences, respectively their power.

First, the investor is confronted with its strategic priorities in terms of strategic objectives and the type of its project idea which could be perceived as a complexity. According to Cova and Salle (2007) there are two possibilities to deal with the complexity of the situation. The first one is to follow the determinist approach by considering the complexity as a fact and to try to adapt to it. The second one is the constructivist approach which suggests that the complexity could be reduced by becoming an actor in the construction of the project. In both cases information is needed in order to find potential suppliers of engineering services.

Second, feasibility analysis comprises an important step in the process of turnkey project implementation as a market entry mode. The focus usually is placed on risk 
analysis and various barriers, incl. tariff and investor usually evaluates the overall non-tariff barriers. This is extremely critical reliability of the feasibility study and takes a for emerging markets especially if there are decision to proceed or to cancel the project. restrictive regulations on foreign entries. The The key success factors of turnkey project

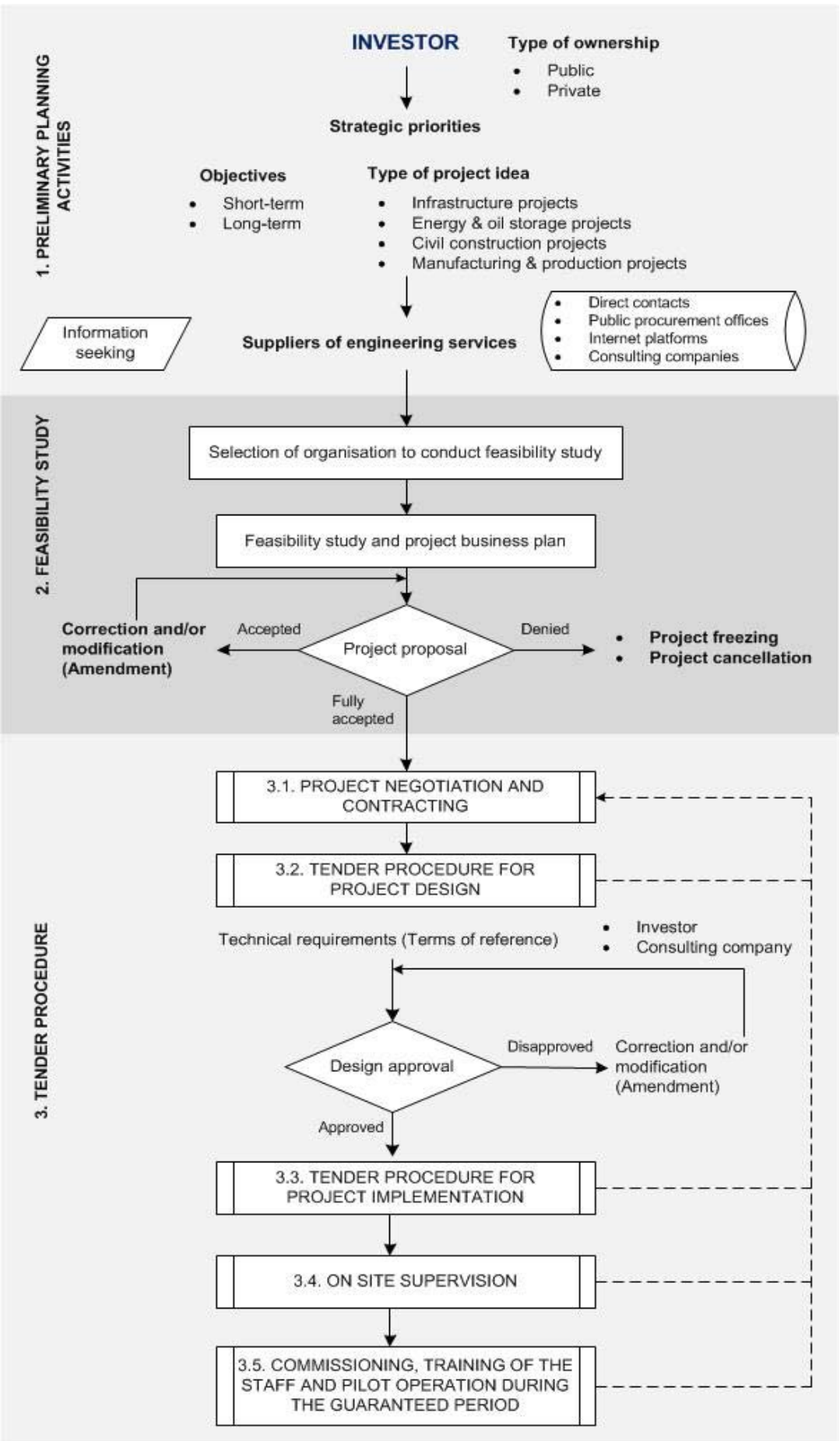

Figure 4. Conceptual model of turnkey project development 
development during the third stage of the process - tender procedure, are numerous but the most important are the financial factors, risk factors and human factor. Capacity to make special financial arrangements and to follow these arrangements during the project implementation is crucial during the whole process. Risk management should be an integral part of each step of the process. Competencies of the personnel are vital for project sustainability.

\subsection{Findings}

\subsubsection{Intervention areas in global markets}

Intervention areas in global markets are analysed using secondary data provided by the Globalisation Index Report and The Global Competitiveness Report. Available relations and their type were tested through regression analysis (Table 5).
Based on received results we can identify three main areas for marketing interventions in global markets, namely financial efficiency, HR skills and business environment. The three of them were mentioned as important for turnkey project development. Business environment interventions could be implemented by affecting country risk levels, infrastructure and security of international property. The second one, infrastructure, is particularly interesting because turnkey projects are usually used to develop and to implement infrastructure projects. Business environment is considered a critical factor during the process of market entry selection and implementation. That is why, its analysis (in different aspects and scopes) is done through the whole process of turnkey project development (Figure 4). The correlation analysis reveals the strongest relationship (Pearson coefficient 0.607, $\alpha=0.000$ ) of the effect of financial efficiency over total assessment of global competitiveness. It

Table 5. Regression analysis, global markets

\begin{tabular}{lllll}
\hline Dependent variable & Independent variable & $\begin{array}{l}\text { Type of } \\
\text { relationship }\end{array}$ & Coefficients & Significance \\
\hline Financial efficiency & Labour expenditures/ & Linear & $\mathrm{a}=0.266$ & 0.000 \\
& wages & $\mathrm{R}^{2}=0.993$ & $\mathrm{~b}=0.416$ & \\
HR skills & Relevant experience & $\begin{array}{l}\text { Linear } \\
\mathrm{R}^{2}=0.923\end{array}$ & $\begin{array}{l}\mathrm{a}=0.747 \\
\mathrm{~b}=0.403\end{array}$ & 0.000 \\
Business environment & Country risk & Linear & $\begin{array}{l}\mathrm{a}=0.139 \\
\mathrm{~b}=0.462\end{array}$ & 0.000 \\
& & $\mathrm{R}^{2}=0.931$ & \\
Business environment & Infrastructure & Linear & $\begin{array}{l}\mathrm{a}=0.016 \\
\mathrm{~b}=1.269\end{array}$ & 0.000 \\
& & $\mathrm{R}^{2}=0.751$ & $(0.911)$ & \\
Business environment & $\begin{array}{l}\text { Security of intellectual } \\
\text { property }\end{array}$ & $\begin{array}{l}\text { Logarithmic } \\
\mathrm{R}^{2}=0.692\end{array}$ & $\begin{array}{l}\mathrm{a}=2.585 \\
\mathrm{~b}=1.137\end{array}$ & 0.000 \\
\hline
\end{tabular}

Secondary data sources: A.T. Kearney: Foreign Policy Globalization Index 2011 Report and World Economic Forum: The Global Competitiveness Report 2011-2012.

Note: In the above table only statistically significant relations between analysed variables are presented. Information about all tested relations could be received by the author under request. The significance values for the coefficients in regression equations in cases when $\alpha>0.05$ is shown in brackets. 
confirms the authors' observations on secondary sources of information that the most frequent interventions on global markets are performed through financial tools.

\subsubsection{Analysis of BRICS countries as} potential host countries for turnkey projects implementation

Present paper focuses on BRICS 10 countries as the most popular emerging markets. For the purposes of analysis several secondary sources of information are used. Countries are comparatively analysed based on the composite elements of the KOF Index of Globalisation, namely economic globalisation, actual flow restrictions, social globalisation, personal contact, information flows, cultural proximity, political globalisation, and the overall globalisation index itself. The results are presented on Figure 5through Figure 10. There is a strong positive tendency toward globalisation for BRICS countries (Figure 5).

As we can see in Figure 6 through Figure 10 there are obvious differences in the structure of the globalisation process between the countries, especially for the elements "personal contact" and "cultural

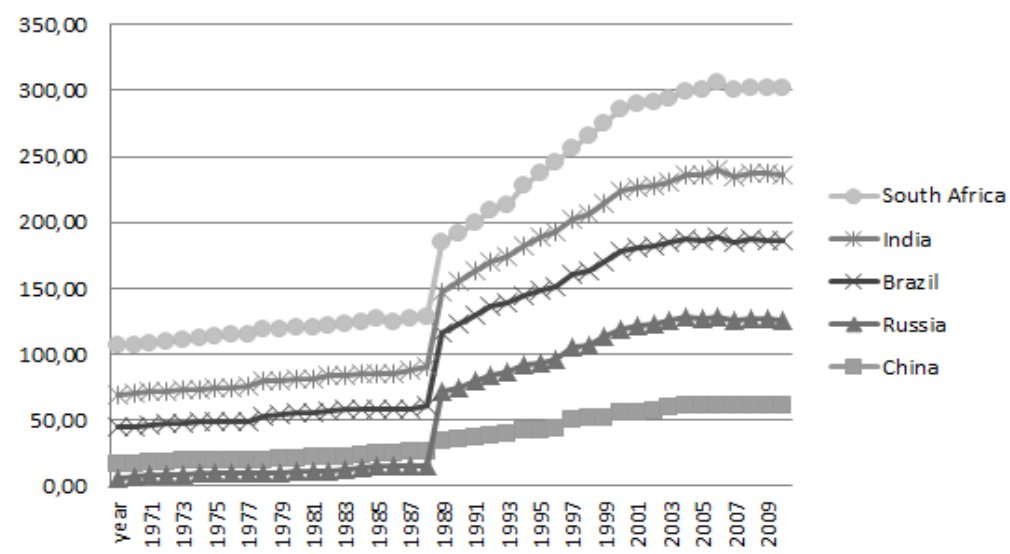

Note: Data are not available for Russia from 1971 to 1989

Source: Data set from http://globalization.kof.ethz.ch/ [last visited on 29.03.2015]

Figure 5. Comparison of BRICS by Overall Globalisation Index (KOF Index of Globalisation), 1971 $-2011$

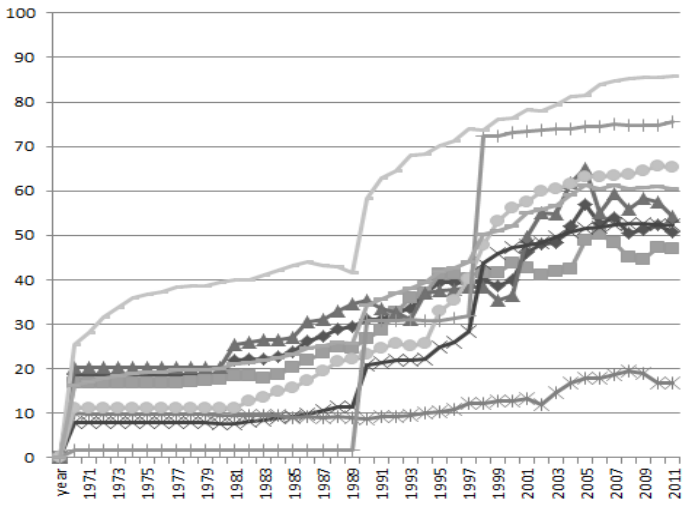

Figure 6. KOF Index of Globalisation for China, $1971-2011$

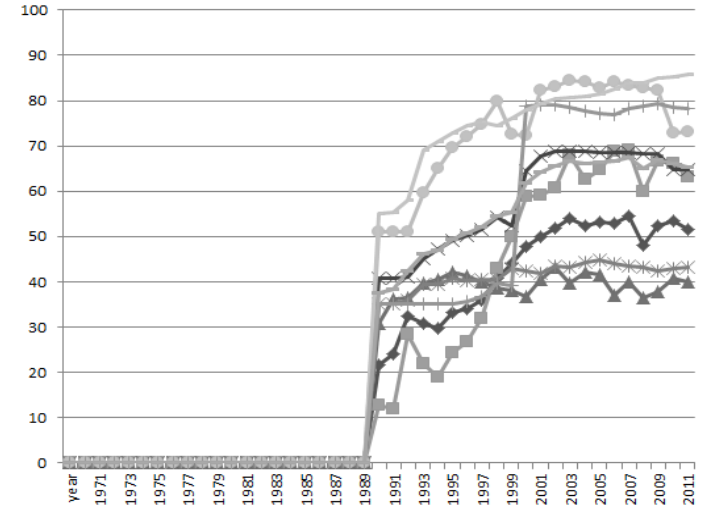

Figure 7. KOF Index of Globalisation for Russian Federation, 1990 - 2011

\footnotetext{
${ }^{10}$ Brasil, Russia, India, China and South Africa
} 
proximity". Two "jumps" in cultural the last two years few negative trends are proximity (1989 and 1997) are evident for observed. There is a slight decline in China (Figure 6). Personal contact still information flows, actual flows and remains at a low level with values quite restrictions. As it was mentioned in the similar to those of India (Figure 9). These factors are analysed further in details because they are considered critical for the third stage of turnkey project development tender procedure.

Russian Federation is an interesting and challenging market because of its instability. As we can see in Figure 7 there is a serious "leap" in cultural proximity in 1998. During

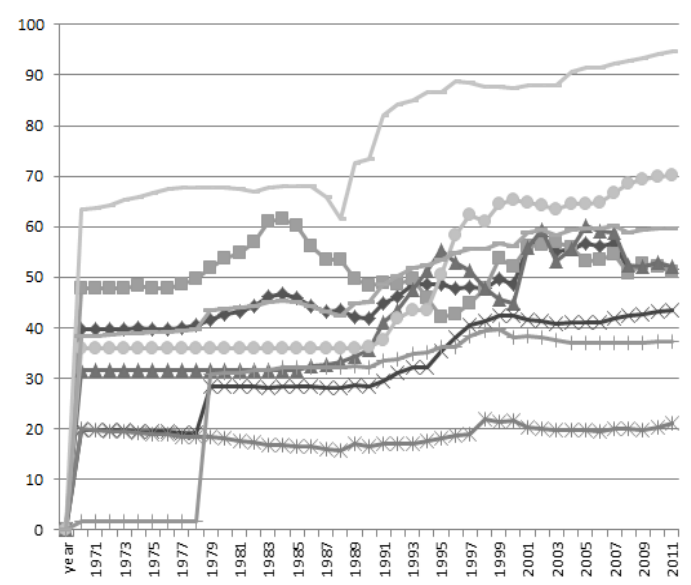

Figure 8. KOF Index of Globalisation for Brazil, $1971-2011$ introductory part of the paper, protectionism is on the rise nowadays which causes problems especially for investment and contractual market entry strategies.

There is a group of scholars and researchers (Distler, 2005; Laudicina, 2012) who suggest that the locus of global economic, political and demographic power has been shifting with growing intensity

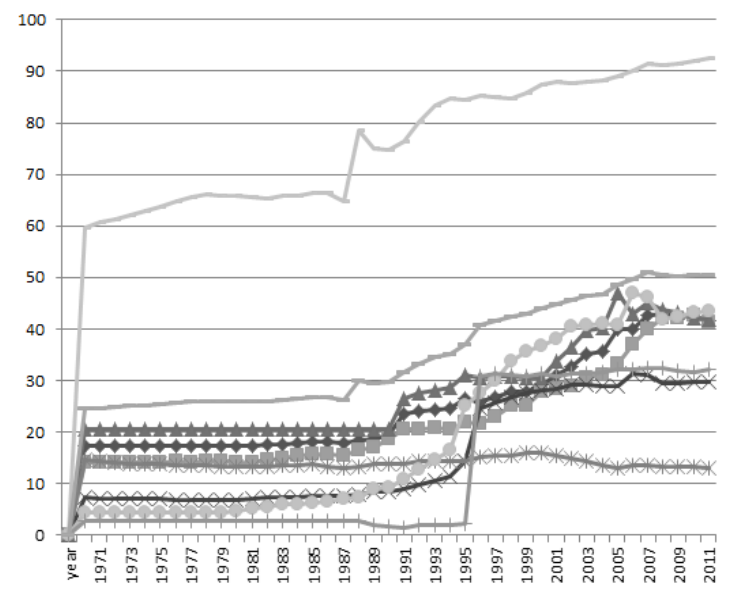

Figure 9. KOF Index of Globalisation for India, $1971-2011$

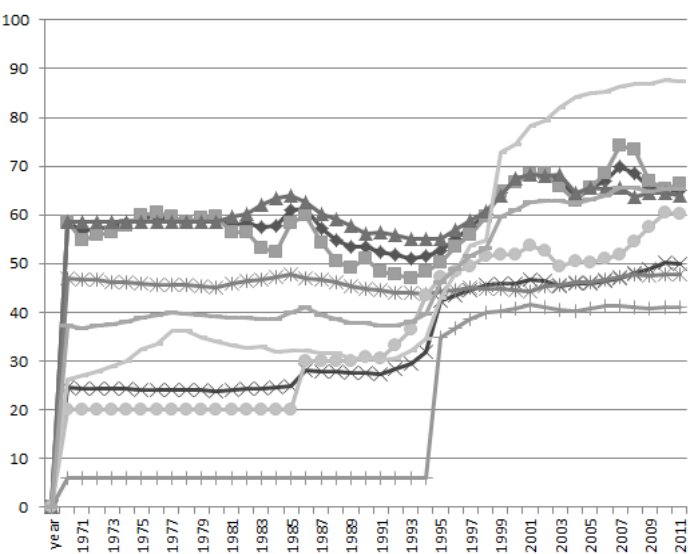

Note: Data are not available for Russia from 1971 to 1989
Source: Data set from http://globalization.kof.ethz.ch/ [last visited on 29.03.2015]

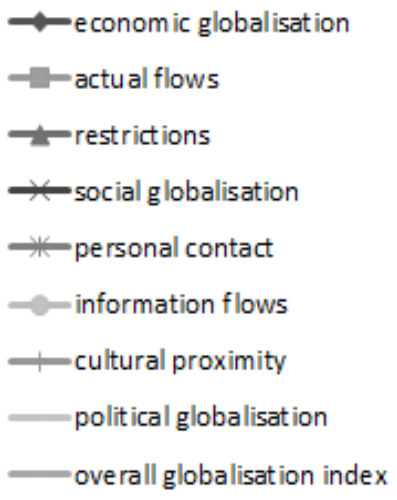

Legend

Figure 10. KOF Index of Globalisation for South Africa, 1971-2011 
from Global North (developed countries) to the rest of the factors is almost flat. There is Global South (developing countries) as well. a substantial rise in cultural proximity in Both trends affect global supply chains 1995 but personal contact didn't change decisions, especially their sourcing locations during the analysed period. Regarding South as well as expansion strategies of the Africa (Figure 10) a sharp improvement in companies. Brazil could serve as a good cultural proximity in 1994 is seen and a example (Figure 8) with few fluctuations steady growth of political globalisation after during the years. India (Figure 9) differs a lot 1994. Information flows and social compared to the rest of the BRICS countries. Political globalisation shows a permanent trend to increase while the growth rate for globalisation are raising as well.

Comparing BRICS country profiles for 2011, it is evident that all countries are at the

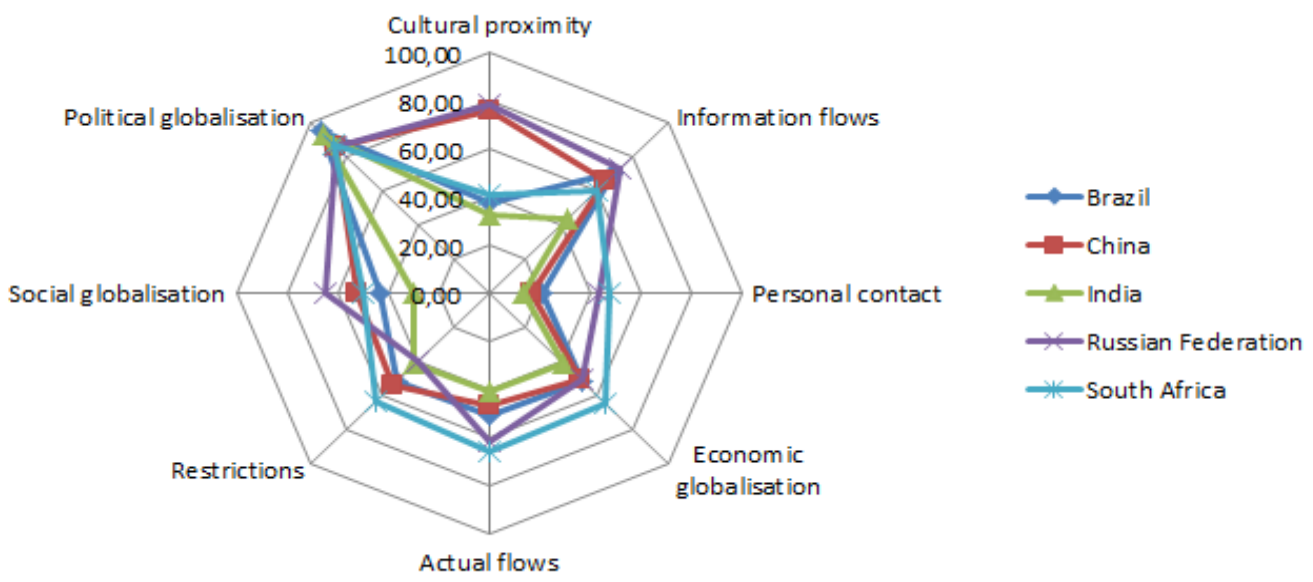

Figure 11. Comparative country profiles by KOF Index variables, 2011

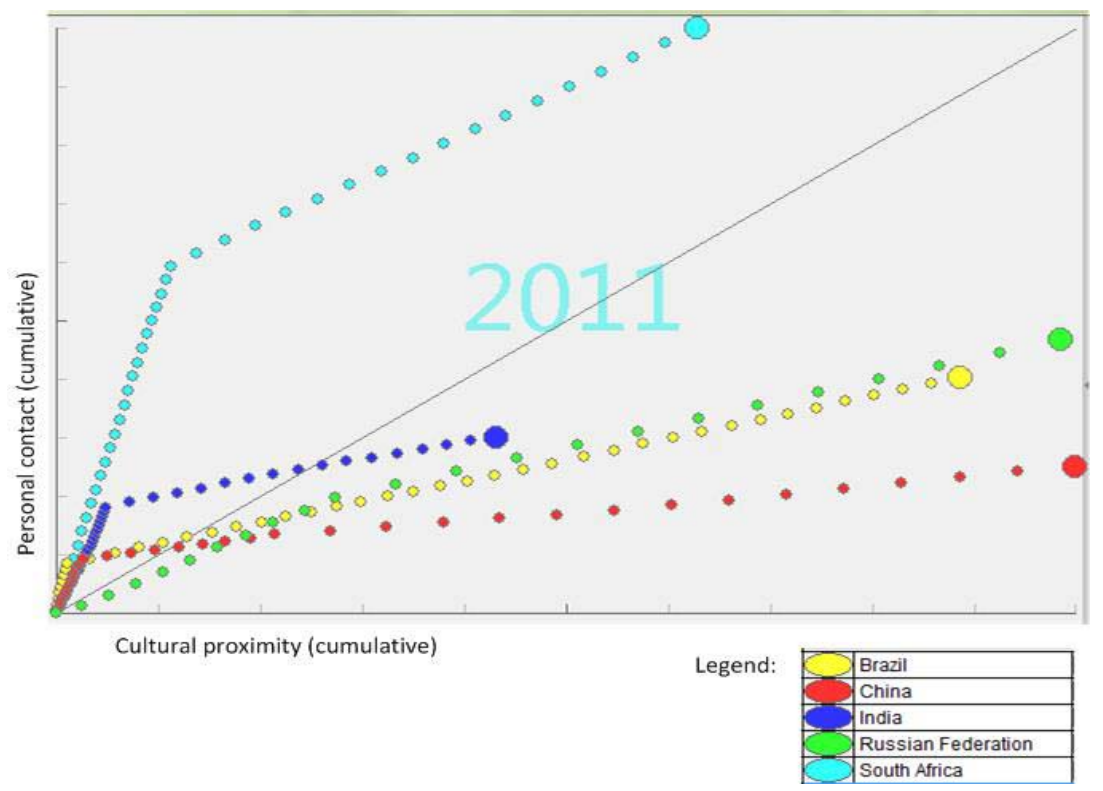

Figure 12. Comparative analysis of BRICS countries by personal contact and cultural proximity, $1970-2011$ 
same (almost maximum) level for political globalisation. Regarding cultural proximity and personal contact, the following subdivision can be done. China and Russia share the same level (around 80) of cultural proximity while the value of this index component for India, Brazil and South Africa fluctuates around 40. As for the personal contact, South Africa and Russia differ substantially from the rest (Brazil, India, and China). Some additional analysis is performed about those two elements of the KOF Index of Globalisation. Data are analysed through data mart software. The visualisation of the results is presented on Figure 12.

The correlation pattern between cultural proximity and personal contact is linear for Brazil, Russia, and China. It is almost identical for Brazil and Russia. These differences can be explained by crosscultural variances between BRICS countries (Figure 13).

Russia and China are quite similar on Power Distance, Indulgence, and Long Term Orientation dimensions. Power Distance deals with the fact that all individuals in societies are not equal. Such countries are quite centralised which increases macro risk levels. The high score on Long Term Orientation suggests that Russia and China are definitely countries with a pragmatic mindset, i.e. people in these countries show an ability to adapt traditions easily to changed conditions. This might have a positive effect during turnkey project negotiation and contracting (tender procedure step 3.1). Russia and China are 'restrained' cultures according to the low score on Indulgence dimension. Societies with a low score in this dimension have a tendency to cynicism and pessimism because of the perception that human actions are restrained by social norms.

Presented results explain the medium country risk levels (Table 6) except Russia and Brazil with higher levels of risk.

The most negative business climate assessment is given to Russian Federation. Itsexplanationis rooted in the following characteristics of Russian economy: lack of or shortcomings in infrastructure; shortcomings in the education system or incomplete education system which leads to lack of qualified labour; bureaucracy and/or corruption; demographic problems; environmental problems.

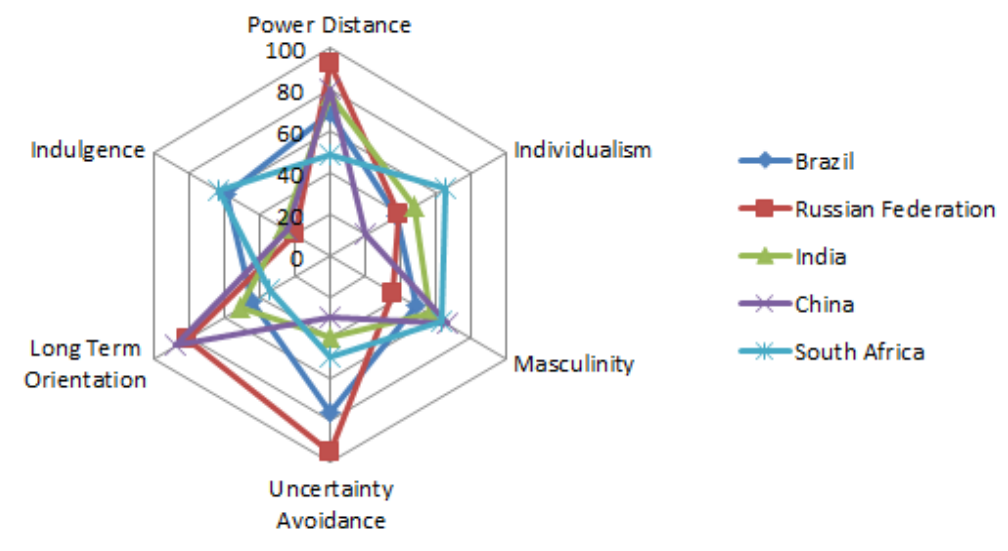

Note: Data were extracted from https://geert-hofstede.com [last access on: 2 July 2016]

Figure 13. Comparative profiles of BRICS countries by Hofstede cultural dimensions 
Table 6. BRIC: Comparative country risk assessment

\begin{tabular}{|c|c|c|c|c|c|}
\hline & Brazil & $\begin{array}{l}\text { Russian } \\
\text { Federation }\end{array}$ & India & China & $\begin{array}{l}\text { South } \\
\text { Africa }\end{array}$ \\
\hline Population, million & 202.768 & 143.7 & 1243.337 & 1367.52 & 54 \\
\hline GDP per capita, US\$ & 11,573 & 12,718 & 1,608 & 7,572 & 6,483 \\
\hline Country risk assessment & $\mathrm{C}$ & $\mathrm{C}$ & A4 & $\mathrm{B}$ & B \\
\hline $\begin{array}{l}\text { Business climate } \\
\text { assessment }\end{array}$ & A4 & $\mathrm{C}$ & $\mathrm{B}$ & $\mathrm{B}$ & A4 \\
\hline
\end{tabular}

Source: COFACE Risk Index ${ }^{11}$ [http://www.coface.com/cofaweb/comparer/697-883-750-266; data are updated on March 2016]

4. CONCLUSIONS IMPLICATIONS FOR RESEARCH

Global markets are constantly evolving. Companies are facing a growing number of both market challenges and business opportunities. Despite the phenomenon of globalisation and deregulation of markets the risk levels of entering foreign markets are still high. To avoid excessive market failures firms should carefully analyse foreign market environment before the choice of international market entry mode. This is especially critical for emerging markets. In such situations contractual entry modes are preferable especially for large projects. Turnkey projects provide an opportunity to enter a foreign market by adapting to the complexity of the environment or even by proactively modifying it.

Several implications for future research were identified.

First, it is interesting to be explored further if the process of turnkey projects development could be used by investors in emerging markets for long-term purposes and especially for further market expansion thus overcoming the discontinuity of project business.
Second, in order to support marketing managers for their strategic market decisions it would be noteworthy to investigate the opportunities for transforming the process of turnkey projects development into profitable business solutions based on networks between investor, suppliers, consultants and other business and non-business actors.

Third, an interesting topic for future research provides the evolution of information technologies and its effect on market entry modes.

\section{References}

Aaby, N.-E., Slater, S.F. (1989). Management influences on export performance: a review of the empirical literature 1978-1988. International Marketing Review, 6 (4), 7-26.

Aaker, D.A. (1989). Managing assets and skills: the key to a sustainable competitive advantage. California Management Review, 31, 91-106.

Abiad, A., Bluedorn, J., Guajardo, J., \&Topalova, P. (2012). The rising resilience of emerging market and developing economies. IMF Working Paper, IMF Strategy, Policy, and Review Department, $\mathrm{WP} / 12 / 300$.

\footnotetext{
${ }^{11}$ In COFACEanalysis a seven-level ranking is used. In ascending order of risk, these are: A1, A2, A3, A4, B, C and D.
} 


\title{
СТРАТЕГИЈЕ ТРЖИШНОГ НАСТУПА У РАСТУЋЕМ ТРШИШНОМ ОКРУЖЕЫУ: КОНЦЕПТУАЛНИ МОДЕЛ РАЗВОЈА ПРОЈЕКТА ПО ПРИНЦИПУ “КЉУЧ У РУКЕ"
}

\author{
Bistra Vassileva, Miroslav Nikolov
}

\begin{abstract}
Извод
Основна сврха овог рада је анализа стратегија интерног тржишног наступа, у светлу процеса глобализације а са циљем предлагања концептуалног модела пројекта по приципу “кључ у руке”. Специфични циљеви истраживања су: 1. развој интегрисаног оквира пројеката по принципу “кључ у руке”, као концептуалног модела; 2. анализа БРИКС земаља као потенцијалних локација за имплементацију ове врсте пројеката; 3. процена потенцијалних имплокација предложеног концептуалног модела као основа стратегије за глобални тржишни наступ.
\end{abstract}

Кључне речи: Стратегија тршишног наступа, “кључ у руке”, БРИКС

Amit, R., \& Schoemaker, P.J.H. (1993). Strategic assets and organizational rent. Strategic Management Journal, 14, 33-46.

Andersen, O. (1993). On the internationalization process of firms: a critical analysis. Journal of International Business Studies, 24 (2), 209-231.

Anderson, E., \&Gatignon, H. (1986). Modes of entry: a transaction cost analysis and propositions. Journal of International Business Studies, 17, 1-26.

Artto, K.A., \&Wikstrom, K. (2005). What is project business? International Journal of Project Management, 23 (5), 343-353.

Barney, J.B. (1991). Firms resources and sustained competitive advantage. Journal of Management, 17 (1), 99-12.

Bartlett, C., \&Ghoshal, S. (1987). Managing across borders: new strategic requirements. Sloan Management Review, 29, 7-17.

Beamish, P.W. (1990). The Internationalization Process For Smaller Ontario Firms: A Research Agenda, In Research In Global Strategic Management-
International Business Research For The Twenty-First Century: Canada's New Research Agenda, Alan M. Rugman, Ed. Greenwich, Ct: Jai Press, 1990, pp. 77-92.

Bharadwaj, S.G., Varadarajan, P.R., \&Fahy, J. (1993). Sustainable competitive advantage in service industries: a conceptual model and research propositions. Journal of Marketing, 58, 83-99.

Bradley, F. (2005). International Marketing Strategy. 5th ed., Financial Times: Prentice Hall, Pearson Education Ltd.

Carman, J.M. (1980). Paradigms for marketing theory. Review in Marketing, 3, 136.

Clarke, T., \& Knowles, L.L. (2003). Global myopia: globalization theory in international business. Journal of International Management, 9 (4), 361-372.

Clark, T., Hodis, M., \& Angelo, P. (2009). The ancient road: an overview of globalization. The SAGE Handbook of International Marketing. SAGE Publications.

Conner, K.R. (1991). A historical 
comparison of resource-based theory and five schools of thought within industrial organization economics: do we have a new theory of the firm? Journal of Management, 17 (1), 121-54.

Cova, B., \&Holstius, K. (1993). How to create competitive advantage in project business. Journal of Marketing Management, 9 (2), 105-121.

Cova, B., \& Salle, R. (2007). Introduction to the IMM special issue on 'Project marketing and the marketing of solutions' A comprehensive approach to project marketing and the marketing of solutions. Industrial Marketing Management, 36, 138146.

Coviello, N., \&Mcauley, A. (1999). Internationalisation and the Smaller Firm: A Review of Contemporary Empirical Research. Management International Review, July 1.

Davidson, W.H. (1982). Global Strategic Management, John Wiley \& Sons, New York, NY.

Dobbs, R., Ramaswamy, S., Stephenson, E., \&Viguerie, P. (2014). Management intuition for the next 50 years. McKinsey Quarterly, September, 2014.

Douglas, S.P., \& Craig, C.S. (1995). Global Marketing Strategy, McGraw-Hill, New York, NY.

Dunning J.H. (1995). Repairing the electric paradigm in the age of alliance capitalism. Journal of International Business Studies, 26 (3), 461-493.

Dunning, J.H. (1977). Trade, location of economic activity and the MNE: a search for an eclectic approach, in Ohlin, B. et al. (Eds), The International Allocation of Economic Activity, Proceedings of a Noble Symposium Held in Stockholm, Macmillan, London.

Dunning, J.H. (1988). The eclectic paradigm of international production: a restatement and some possible extensions. Journal of International Business Studies, 19 (1), 1-31.

Dunning J.H. (2001). The eclectic (OLI) paradigm of international production: past, present and future, International Journal of the Economics of Business, 8 (2), 2001, 173 190.

Ekeledo, I.,\&Sivakumar, K. (2004). International market entry mode strategies of manufacturing firms and service firms: a resource-based perspective. International Marketing Review, 21 (1), 68-101.

Garelli, P.S. (2007). The competitiveness roadmap: 2007-2050, IMD World Competitiveness Yearbook 2007.

Gatignon, H., \& Anderson, E. (1988). The multinational corporation's degree of control over foreign subsidiaries: an empirical test of a transaction cost explanation. Journal of Law, Economics and Organization, 4, 30536.

Grant, R.M. (1991). The resource-based theory of competitive advantage: implications for strategy formulation. California Management Review, 33, 114135.

Hadjikhani, A., \&Thilenius, P. (2005). Non Business Actors in a Business Network. Amsterdam Elsevier.

Johanson, J., \&Vahlne, J.-E. (1977). The internationalization process of the firm - a model of knowledge development and increasing foreign market commitment. Journal Of International Business Studies, 8, 23-32.

Johanson, J., \&Vahlne, J.-E. (1990). The mechanism of internationalization. International Marketing Review, 7 (4), 1124.

Johanson, J., \&Vahlne, J.-E. (1992). Management of foreign market entry. Scandinavian International Business Review, 
1 (3), 9-27.

KPMG (2011). Confronting Complexity, KPMG International Cooperative.

Lymbersky, C. (2008). Market Entry Strategies: Text, Cases and Readings in Market Entry Management, 1st edition, Management Laboratory Press.

Madhok, A. (1997). Cost, value and foreign market entry mode: the transaction and the firm. Strategic Management Journal, 18, 39-61.

Mandják, T., \&Veres, Z. (1998). The D-U$\mathrm{C}$ model and the stages of project marketing process. Proceedings of the 14th IMP Conference, Turku: Turku School of Economics and Business Administration, 471-490.

Nielsen, L. (2011). Classifications of countries based on their level of development: how it is done and how it could be done. IMF Working Paper, IMF Strategy, Policy, and Review Department, WP/11/31.

Ohmae, K. (1989). The global logic of strategic alliances. Harvard Business Review, March-April, pp. 143-154.

Reve, T., \& Stern, L.W. (1979). Interorganisational relations in marketing channels. Academy of Management Review, 4 (3), 405-416.

Root, F.R. (1994). Entry Strategies for International Markets, D.C. Heath, Lexington, MA.

Rugman, A.M. (1980). Internalization as a general theory of foreign direct investment: a reappraisal of literature, WeltwirtschaftlichesArchiv, 116 (2), 365-79.

Ryder, I. (2005). Issues and patterns in global branding. In: Securing the Business Benefits of Globalisation: A European Perspective, Distler, C. \&Nivollet, B. (Eds.), Part IV, Chapter 2, 205-226, Unisys.
Sweeney, D.J. (1972). Management technology or social process, Journal of Marketing, 36, 3-10.

Teece, D. (1983). Technological and organisational factors in the theory of multinational enterprise, in Mark Casson (ed.), The Growth of International Business, Allen and Unwin, London, 1983, pp. 51-62.

Terpstra, V., \&Sarathy, R. (1994), International Marketing, 6th ed., Dryden Press, Fort Worth, TX.

Thoumrungroje, A. (2004). The effects of globalization on marketing strategy and performance, Dissertation, Washington State University, College of Business and Economics.

Van de Ven, A.H., Emmett, D., \& Koenig, Jr. H. (1974). Frameworks for InterOrganizational Analysis, Organization and Administrative Sciences, 5 (1), 113-129.

Welch, C. (2005). Multilateral organisations and international project marketing. International Business Review, 14 (3), 289-305.

Welch, L. \&Luostarinen, R.K. (1993). Inward and outward connections in internationalization. Journal of International Marketing, 1 (1), 46-58.

Williamson, O.E. (1975). Markets and Hierarchies: Analysis and Antitrust Implications. New York: The Free Press.

Williamson, O.E. (1981). The economics of organization. The transaction cost approach. American Journal of Sociology, $87,548-577$. 